\title{
Menuju Surabaya Green City Melalui Kerjasama Kota Kembar Surabaya-Kitakyushu
}

\author{
Fany Widiana ${ }^{1}$ dan Ario Bimo Utomo ${ }^{2}$ \\ Universitas Pembangunan Nasional "Veteran" Jawa Timur
}

\begin{abstract}
The sister city collaboration between Surabaya and Kitakyushu is an example of the active cooperation of local governments in Indonesia. Conceptually, this kind of cooperation is also called paradiplomacy or diplomatic activity carried out by local governments with other regions in foreign countries. This article takes a case study of the sister cities of Surabaya and Kitakyushu to then look at the institutionalization aspect as a dimension that can be seen from paradiplomacy. Using the Surabaya point of view, the institutionalization points that the writer will review in this article are (1) the formation of a special ministry or department; (2) establishment of permanent subnational offices; (3) official visits of regional authorities to foreign territories and countries; (4) participation in various international events organized by foreign actors; (5) formation and participation in multilateral global \& cross-border regional networks and working groups in specific fields; and (6) regional authorization participation in international events organized by foreign entities in official delegations of the central government.
\end{abstract}

\section{Keywords: paradiplomacy, Surabaya, Kitakyushu, sister city, institutionalisasi.}

\section{PENDAHULUAN}

Kota Surabaya dan Kota Kitakyushu telah aktif melakukan kerjasama pada bidang lingkungan dari tahun 1997 saat penandatanganan Joint Declaration of The Kitakyushu Conference on Environmental Cooperation among Cities in The Asian Region. Keduanya lalu memutuskan untuk melanjutkan kerjasama ke jenjang yang lebih tinggi dan lebih kompleks, yaitu kerjasama paradiplomasi bertajuk Green Sister City of Surabaya-Kitakyushu yang ditandai dengan penandatanganan MoU oleh Walikota Surabaya Tri Rismaharini dan Walikota Kitakyushu Kenji Kitahashi di Surabaya pada tahun 2012 (Pandia, 2012).

Paradiplomasi adalah kata yang tepat untuk mendefinisikan kegiatan yang dilakukan oleh aktor subnasional untuk berkontribusi dalam dunia internasional. Paradiplomasi adalah partisipasi aktor subnasional dalam berbagai kegiatan internasional dengan kekuatan asing memberikan power untuk mempromosikan kepentingannya sendiri (Kuznetsov, 2014: 1). Secara umum, paradiplomasi didefinisikan dimana peran diplomasi oleh pemerintah pusat diambil alih oleh pemerintah daerah yang bekerjasama dengan daerah lain dalam ranah hubungan internasional. Di Indonesia, terjadinya paradiplomasi tak luput dari adanya dukungan dari pemerintah pusat dengan diberikannya otonomi daerah (Octavia, 2017). Selain itu, adanya Undang-undang No.24 Tahun 2000 tentang Perjanjian Internasional dan 
Undang-undang No.32 tahun 2004 tentang Pemerintah Daerah, memberikan peluang gerak dan kewenangan yang lebih kepada pemerintah daerah untuk mengembangkan potensi dan sumber daya dalam hubungan kerja sama internasional.

Hal yang melatarbelakangi kerjasama ini adalah masalah lingkungan yang dialami Surabaya. Selayaknya perkotaan besar pada umumnya, Surabaya juga merupakan kota yang cukup padat, jumlah penduduknya terbanyak kedua setelah Jakarta (Kemendagri Indonesia, 2019). Sektor penopang perekonomian Surabaya yang paling besar menyumbang Produk Domestik Regional Bruto (PDRB) adalah sektor Perdagangan, Hotel dan Restoran sebesar 38,96\%. Lalu diikuti sektor Industri Pengolahan berkontribusi sebesar 27,21\% (Diskominfo Surabaya, 2020). Permasalahan-permasalahan yang biasa terjadi pada kota besar seperti Surabaya adalah permasalahan lingkungan, terutama sampah. Pada tahun 2003 Surabaya mengalami masalah besar sampah, kurangnya lahan hijau membuat hampir 50 persen dari total wilayah Surabaya mengalami banjir saat musim hujan (Humas Surabaya, 2018). Selain itu, pada awal tahun 2000, Surabaya pernah mengalami "banjir sampah" yang diakibatkan penutupan Lahan Pembuangan Akhir (LPA) Keputih oleh warga setempat. Akibatnya, sampah berserakan di setiap sudut kota (Tempo.co, 2003).

Pemerintah kota Surabaya menyadari bahwa akan sulit menyelesaikan masalah sampah karena keterbatasan kemampuan dan teknologi. Oleh karena itu Surabaya membutuhkan partner yang sudah berpengalaman untuk membantu menyelesaikan masalah tersebut, yaitu kota Kitakyushu. Selain itu, Surabaya dan Kitakyushu memiliki kesamaan kondisi, yakni sama-sama kota industri yang mengalami masalah lingkungan dan sampah serupa. Sekitar tahun 1960, kondisi kota Kitakyushu hampir sama seperti Surabaya. Asap dan limbah industri merupakan pemandangan yang lazim pada saat itu, membuat langit terlihat abu-abu dan air sungai menjadi kotor. Akibat kesadaran warga dan dukungan pemerintah, Kota Kitakyushu sekarang telah berhasil melakukan pembangunan ramah lingkungan menggunakan green technology. Karenanya dikenal dengan sebutan Smart City, dimana sektor industri yang terus berkembang pesat namun tetap ramah lingkungan bagi penduduknya (Ridwan, 2015a, 2015b).

Dalam setiap kerjasama, masing-masing aktor memiliki kepentingannya sendiri. Jika kepentingan Surabaya adalah untuk mempelajari cara Kitakyushu dalam mengolah sampah, kepentingan Kitakyushu dalam kerjasama sister city ini adalah menjadi pusat Asia untuk masyarakat rendah karbon. Dengan terlibat dalam kerjasama city to city, Kitakyushu akan mengembangkan interaksi yang berfokus pada hubungan antar kota, hal tersebut akan 
membantu Jepang mendapatkan rasa hormat dari masyarakat internasional untuk berkontribusi pada penciptaan kota hijau di Asia (City of Kitakyushu, 2016).

\section{KERANGKA PEMIKIRAN \\ Paradiplomasi \& Institusionalisasi Paradiplomasi}

Paradiplomasi merupakan singkatan dari 'parallel diplomacy' yang pertama kali diluncurkan dalam perdebatan akademik oleh ilmuwan asal Basque, Panayotis Soldatos tahun 1980-an (Criekemans, 2008: 34). Paradiplomasi secara definisi merupakan keterlibatan pemerintah subnasional lokal maupun regional dalam hubungan atau aktivitas internasional (Duchacek, 1984: 9). Definisi lain dari paradiplomasi adalah sebagai kapasitas dan partisipasi entitas subnegara dalam arena internasional untuk mencapai kepentingan spesifik (Wolff, 2007). Aktor subnasional saat ini diakui sebagai aktor internasional, karena aktor subnasional tersebut mampu menegosiasikan dan menandatangani kesepakatan internasional dengan negara asing dan aktor-aktor non pemerintah, membangun perwakilan di luar negeri, melakukan misi dagang, mencari investasi asing, dan membangun hubungan bilateral maupun multilateral dengan negara-negara (Lecours, 2002: 92). Keterlibatan aktor subnasional tersebut lebih mencakup kepada konteks-konteks kerja sama yang sifatnya nontradisional atau low politics, seperti ekonomi, sosial, budaya, pendidikan, lingkungan, dan bentuk lainnya yang tidak secara langsung mengarah kepada keamanan nasional maupun status diplomatik. Secara tradisional, pengambilan keputusan low politics lebih terkonsentrasi pada otoritas daerah dan lokal, sementara high politics milik pemerintah pusat (Duchacek, 1984).

Gambar 1. Kerangka Analisis Paradiplomasi

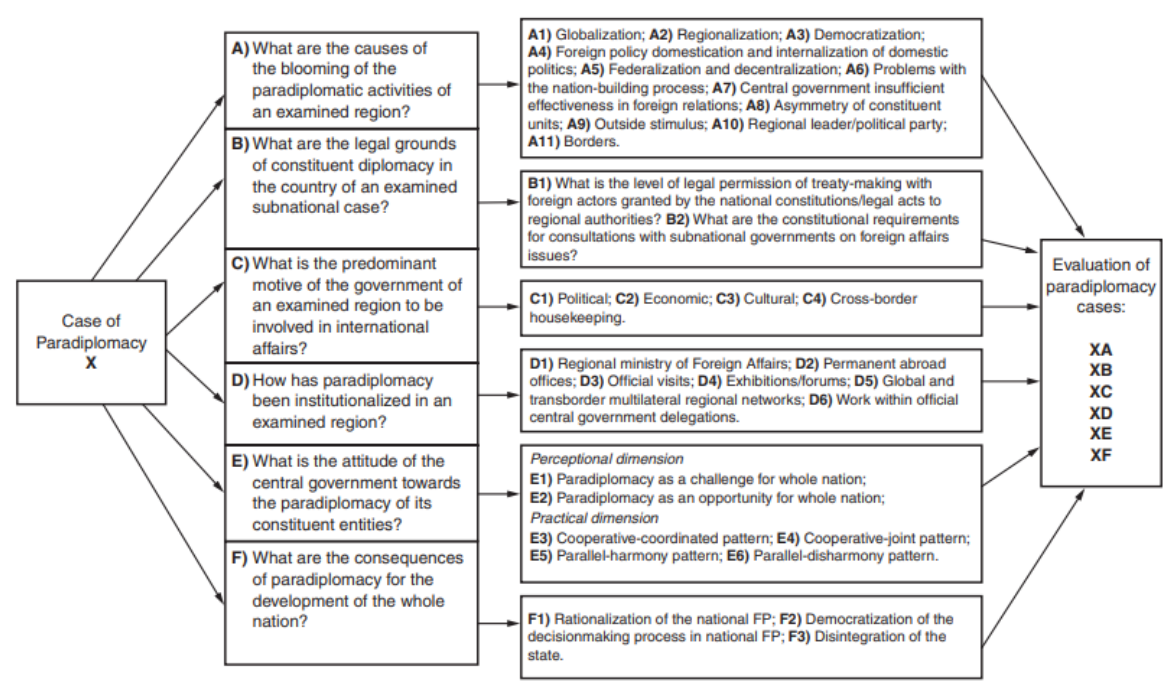

Sumber: Kuznetsov, 2014: 116 
Kuznetsov dalam bukunya yang berjudul "Theory and Practice of Paradiplomacy: Subnational Government in International Affairs" menjabarkan bagaimana paradiplomasi dalam sebuah kerangka berpikir untuk menjawab pertanyaan-pertanyaan seputar bagaimana entitas subnasional dapat berkiprah di dunia internasional. Dalam kerangka tersebut (Gambar 1) Kuznetsov menyebutkan terdapat enam identifikasi untuk menganalisis kegiatan paradiplomasi, antara lain: identifikasi penyebab terbentuknya aktivitas paradiplomasi; identifikasi dasar hukum dari paradiplomasi; identifikasi motif utama pemerintah daerah untuk terlibat dalam hubungan internasional; identifikasi institusionalisasi dari aktivitas paradiplomasi; identifikasi tanggapan/sikap pemerintah pusat terhadap paradiplomasi; dan identifikasi konsekuensi paradiplomasi terhadap pembangunan negara (Kuznetsov, 2014: 116).

Institusionalisasi dalam paradiplomasi berbicara tentang bagaimana kerjasama paradiplomasi dilembagakan. Untuk dapat melampaui batas negara, tentu melalui proses penjajakan. Penjajakan secara umum didefinisikan sebagai langkah awal yang dilakukan oleh masing-masing pihak yang akan melakukan kerjasama mengenai kemungkinan perjanjian tertentu, sebelum kerjasama diresmikan. Identifikasi institusionalisasi dimulai saat kerjasama tersebut telah resmi dilakukan, ditandai dengan penandatangan nota kesepahaman oleh kedua belah pihak. Kuznetsov memang tidak menyebutkan secara langsung dalam bukunya, tetapi dalam contoh penggunaan kerangka analisis pada suatu studi kasus yang dipaparkan, dapat disimpulkan bahwa institusionalisasi dilakukan saat kerjasama telah berjalan (Kuznetsov, 2014).

Berbicara tentang institusionalisasi tidak lepas dari institusi atau lembaga. Lembaga sendiri muncul tidak langsung utuh dan tetap, tetapi berkembang melalui proses institusionalisasi tadi. Christer Jönsson dan Martin Hall (2005) mengaitkan institusionalisasi dengan konsep social space. Social space merupakan arena atau situasi yang berulang dimana aktor saling mengarahkan tindakannya secara berulang-ulang. Social space dapat dikatakan "terinstitusionalisasi" ketika ada sistem aturan dan prosedur yang digunakan bersama untuk menentukan aktor yang bermain, bagaimana aktor tersebut memahami tindakan satu sama lain, dan jenis tindakan apa yang mungkin dilakukan. Dapat dikatakan bahwa institusionalisasi adalah proses dimana social space muncul dan berkembang. Berdasarkan penjelasan tersebut, institusionalisasi dapat dipahami sebagai sesuatu yang mengkoordinasikan dan membuat pola perilaku dan menyalurkannya ke satu arah yang memungkinkan. Menurut beberapa pengamat, diplomasi baru diinstitusionalisasikan pada abad ke-17. Ditandai dengan 
terbentuknya kedutaan-kedutaan permanen, munculnya sistem kenegaraan serta rumusan seperangkat pemikiran tentang diplomasi dan munculnya teks-teks diplomatik (Jönsson \& Hall, 2005: 40).

Kuznetsov membuat daftar institusionalisasi yang potensial digunakan oleh pemerintah subnasional untuk aktivitas paradiplomatiknya. Terdapat enam institusionalisasi, di antaranya: (1) Pembentukan kementrian atau departemen khusus terpisah yang bertanggung jawab untuk menangani urusan internasional dari unit konstituen; (2) Pembentukan kantor subnasional permanen di luar negeri; (3) Kunjungan resmi otoritas regional ke wilayah dan negara asing; (4) Partisipasi dalam berbagai acara internasional yang diselenggarakan aktor asing; (5) Pembentukan dan partisipasi dalam jaringan global \& lintas batas regional multilateral dan kelompok kerja pada bidang tertentu seperti pertanian, pembangunan berkelanjutan, energi, transportasi, dll; (6) Partisipasi otorisasi daerah dalam acara internasional yang diselenggarakan oleh entitas asing dalam delegasi resmi pemerintah pusat. Ke-enam poin tersebut dapat digunakan oleh aktor subnasional untuk aktivitas paradiplomatiknya, artinya ke-enam poin tersebut tidak harus ada, namun dapat memuat beberapa diantaranya. Pernyataan tersebut ditulis secara eksplisit oleh Kuznetsov dalam bukunya pada bab dimana ia mencontohkan penggunaan kerangka analisis institusionalisasi terhadap salah satu kasus paradiplomasi:

"There are six principal channels and organizational format that Alberta can use in different degrees for its paradiplomatic activities... In different degrees all above-mentioned, channels are used by the province" (Kuznetsov, 2014: 140).

\section{HASIL DAN PEMBAHASAN}

\section{Green Sister City Surabaya-Kitakyushu}

Pada tahun 2012 bulan November, terbentuklah sebuah kerjasama paradiplomasi oleh Pemerintah Kota Surabaya dengan Pemerintah Kota Kitakyushu bertajuk Green Sister City yang ditandai dengan penandatangan MoU Sister City of Surabaya Kitakyushu in Surabaya Green Sister City oleh kedua Walikota. MoU tersebut berisikan tentang Surabaya Green City dengan tiga aspek utama yaitu mewujudkan masyarakat hijau (Green Society), mengembangkan daur ulang dan capacity building yang berfokus pada lingkungan. Selama tahun 2012 hingga tahun 2019, Pemerintah Kota Surabaya dan Kitakyushu telah melakukan hubungan kerjasama dengan membuat program-program untuk mewujudkan Surabaya menjadi Kota Hijau. Program-program tersebut diantaranya: Konsep Kota Rendah Karbon dan Program Daur Ulang; Water Management; Penggalian Potensi Kota; Pengolahan Air Minum; 
Pengelolaan Sumber Energi; Penanggulangan Demam Berdarah; Pelestarian Hutan dan Pengembangan Ekowisata. (Kerjasama Surabaya, no date).

Tabel 1. Program Green City melalui Kerangka Sister City Surabaya-Kitakyushu

\begin{tabular}{|c|c|}
\hline Tahun & Program Surabaya Green City \\
\hline 2012 & Konsep Rendah Karbon dan Program Daur Ulang \\
\hline 2013 & Water Management \\
\hline 2014 & Penggalian Potensi Kota \\
\hline 2015 & Pengelolaan Sumber Energi \\
\hline 2016 & Penanggulangan Demam Berdarah \\
\hline 2017 & Pelestarian Hutan dan Pengembangan Ecowisata \\
\hline 2018 & Sumum \\
\hline
\end{tabular}

Sumber: Fauzia, 2019: 43

\section{Institusionalisasi Paradiplomasi Sister City Surabaya-Kitakyushu}

a. Pembentukan Kementerian/Departemen Terpisah Khusus

Selayaknya kerjasama bilateral antar negara, kerjasama paradiplomasi juga tampaknya membutuhkan lembaga birokrasi khusus yang menangani segala hal yang berkaitan dengan kerjasama. Selanjutnya penting untuk mengklasifikasi apakah lembaga ini memiliki kendali penuh atas hubungan internasional regional atau apakah termasuk cabang otoritas subnasional lainnya yang memiliki divisi sendiri yang mewujudkan proyek internasional. Dalam kerjasama paradiplomasi ini, pembentukan kementerian atau departemen regional khusus yang bertanggung jawab atas urusan internasional tampaknya pilihan yang tepat bagi otoritas subnasional agar proses kerjasama lebih tertata. Kota Surabaya telah memiliki departemen khusus yang bertanggung jawab atas urusan kerjasama, yaitu Bagian Administrasi Kerjasama, yang terbagi atas 3 Subbagian, di antaranya: (1) Subbagian Administrasi Kerjasama Luar Negeri; (2) Subbagian Administrasi Kerjasama Dalam Negeri; (3) Subbagian Pelaporan dan Evaluasi Kerjasama. Subbagian Administrasi Kerjasama Luar Negeri, sesuai dengan namanya, khusus menangani segala sesuatu yang berkaitan dengan urusan kerjasama dengan aktor luar negeri, termasuk salah satunya kerjasama paradiplomasi dengan Kitakyushu. Tugas Subbagian Administrasi Kerjasama Luar Negeri telah diatur dalam 
Peraturan Walikota Surabaya No. 44 Tahun 2016 tentang Uraian Tugas dan Fungsi Sekretariat Daerah Kota (Walikota Surabaya, 2016).

b. Pembentukan Kantor Subnasional Permanen di Luar Negeri

Kantor subnasional di luar negeri biasanya disebut sebagai "paraconsulates", karena fungsinya sebagai pemberi dukungan dan konsultasi bagi komunitas regional dalam mengembangkan kontak internasional dalam bisnis, budaya, dan bidang lainnya (Kuznetsov, 2014: 112). Sama seperti Kantor Konsulat pada umumnya yang mewakili entitas nasional yaitu negara, maka parakonsulat mewakili sebuah entitas subnasional, baik kota/kabupaten atau provinsi. Dalam kasus kerjasama paradiplomasi Surabaya dengan Kitakyushu, pembukaan kantor subnasional permanen di luar negeri tidak mungkin dilakukan karena merujuk pada Permendagri No. 25 Tahun 2020 tentang Tata Cara Kerja Sama Daerah dengan Pemerintah Daerah di Luar Negeri (KSDPL) dan Kerja Sama Daerah dengan Lembaga di Luar Negeri (KSDLL). Dalam Pasal 5 Ayat 1 Poin (c), disebutkan bahwa "Pemerintah Daerah tidak membuka kantor perwakilan di luar negeri”. Pada poin peraturan tersebut jelas menerangkan bahwa setiap daerah di Indonesia yang melakukan kerjasama dengan aktor luar negeri tidak dapat membuka kantor perwakilannya di luar negeri, karena hak untuk membuka kantor diplomatik merupakan domain eksklusif yang dimiliki oleh pemerintah pusat dalam kasus Indonesia (Republik Indonesia, 2020).

c. Melakukan Kunjungan Resmi

Kunjungan resmi otoritas regional ke wilayah dan negara asing, Otoritas regional dalam hal ini adalah delegasi yang ditugaskan melakukan kunjungan resmi ke wilayah mitra kerjasama, dalam hal ini bisa pemimpin daerah, kementerian daerah, perwakilan legislatif, LSM, pengusaha, dan lain sebagainya menyesuaikan dengan maksud dan tujuan kunjungan. Poin ini, menunjukkan bahwa semakin sering otoritas daerah melakukan kunjungan dinas ke luar negeri, maka semakin baik hubungan kedua belah pihak. Kunjungan resmi ini juga menunjukkan level kompetensi dari delegasi dan level dari mitra tuan rumah asing (Kuznetsov, 2014: 123). Baik Surabaya maupun Kitakyushu telah melakukan kunjungan resmi mereka, diantaranya:

Pada 28-29 Maret 2017, KBRI Tokyo melakukan kunjungan ke Kota Kitakyushu dalam rangka berpartisipasi dan mendampingi delegasi DPRD Kota Surabaya dalam kegiatan monitoring dan evaluasi kerjasama sister city (KBRI Tokyo, 2017). Pada 9-13 Januari 2017, delegasi Kota Kitakyushu melakukan kunjungan ke Kota Surabaya dalam rangka tindak lanjut kerjasama green sister city dalam bidang pengelolaan air minum dan penanggulangan demam 
berdarah di Kota Surabaya. Lalu pada 6-7 Februari 2018, delegasi Kota Kitakyushu kembali melakukan kunjungan ke Surabaya untuk meninjau kelanjutan rencana kerjasama green sister city sekaligus identifikasi kebutuhan dan prioritas kerjasama di masa mendatang terkait pemanfaatan hutan mangrove untuk ekowisata di Surabaya dan kajian studi Pengembangan Zona Air Minum Prima (ZAMP) di daerah Ngagel Titro (Kerjasama Surabaya, 2018a, 2018b).

\section{d. Partisipasi Dalam Berbagai Event Internasional}

Event internasional yang dimaksud bisa berbentuk pameran, forum, dan lain-lain yang diselenggarakan oleh aktor asing (Kuznetsov, 2014: 123). Surabaya sebagai partner kerjasama paradiplomasi Kitakyushu telah berpartisipasi dalam beberapa event internasional yang diselenggarakan oleh mitra. Yang pertama, Wali Kota Surabaya pernah menjadi pembicara dalam The $3^{\text {th }}$ International Forum on The "Future City" Initiative di Kitakyushu pada tahun 2013. "Future City" Initiative dipromosikan oleh pemerintah Jepang untuk mengantisipasi tren urbanisasi di seluruh dunia di masa depan. Tujuannya adalah untuk mewujudkan kota dan masyarakat perkotaan dengan sistem sosial dan ekonomi berkelanjutan yang dapat merespon isu-isu penuaan dan lingkungan (Government Of Japan, no date). Yang kedua, delegasi Surabaya berpartisipasi dalam OECD Mayor's Forum: Urban Green Growth in Dynamic Asia pada Oktober 2013. Proyek Urban Green Growth in Dynamic Asia adalah proyek yang mengeksplorasi bagaimana mempromosikan pertumbuhan hijau di kota-kota di Asia, memeriksa kebijakan dan praktik tata kelola yang mendorong keberlanjutan lingkungan dan daya saing dalam ekonomi yang berkembang pesat (OECD, 2016). Kitakyushu bersama dengan OECD dan UNCRD menyelenggarakan forum ini yang merupakan bagian dari konferensi internasional Future Cities (UNCRD, 2013).

e. Pembentukan/Partisipasi dalam Jaringan Global dan Lintas Batas Multilateral Regional

Jaringan regional maupun kelompok kerja masalah spesifik misalnya pada bidang pertanian, pembangunan berkelanjutan, energi, transportasi, dan lain-lain. Beberapa contoh jaringan subnasional yang eksis di kancah internasional seperti nrg4SD, the Conference of New England Governors and Eastern Canadian Premiers (NEG-ECP), the Assembly of European Regions (AER), Lake Constance Conference dan lain-lain (Kuznetsov, 2014: 123).

Dalam kasus ini, kerja sama antara Surabaya dan Kitakyushu terfasilitasi oleh sebuah forum bernama Kitakyushu Initiative for a Clean Environment. Jejaring yang dibentuk sebagai hasil dari Ministerial Conference on Environment and Development in Asia and the Pacific pada tahun 2000 
di Kitakyushu ini dibentuk sebagai wadah untuk mewujudkan pembangunan standar lingkungan melalui proyek-proyek serta diseminasi informasi melalui pelatihan dan seminar. Hal ini dilakukan untuk meningkatkan kapasitas kota mitra dalam membangun kesadaran lingkungan. Berdasarkan situs resminya, tujuan dari adanya Kitakyushu Initiative for a Clean Environment adalah: (1) membantu proses persiapan dan implementasi rencana pembangunan berkelanjutan dengan indikator kuantitatif; (2) memberi pengawasan periodik mengenai implementasi dan progres program; (3) mempromosikan pertukaran informasi dan pengalaman; (4) menyediakan wadah transfer teknologi, tips, serta contoh proyek yang berhasil sebagai model pembangunan berkelanjutan; (5) menyediakan jejaring, katalis, serta fasilitas untuk pendanaan internal maupun eksternal; (6) memfasilitasi aktivitas peningkatan kapasitas bagi staf administratif di bidang lingkungan; (7) mempromosikan pendidikan lingkungan dalam kerja sama antarkota; dan (8) mendorong swasta untuk berpartisipasi dalam pembangunan infrastruktur serta peningkatan kapasitas lingkungan (Kitakyushu Initiative for a Clean Environment, no date).

f. Partisipasi dalam Acara Internasional sebagai Delegasi Resmi Pemerintah Pusat Dalam kerjasama paradiplomasi yang dilakukan oleh aktor subnasional, secara tidak langsung pasti akan melibatkan pemerintah pusat karena secara hierarki otoritas tertinggi terletak pada negara. Jalur keterlibatan entitas subnasional dalam hubungan internasional pada poin ini memiliki dua dampak. Pertama, otoritas daerah artinya dapat loncat menuju tahapan yang tertinggi urusan dunia, hal tersebut memiliki dampaknya sendiri bagi politik luar negeri nasional. Sedangkan akses tahapan tertinggi hubungan internasional tersebut sangat bergantung pada keinginan pemerintah pusat, maka dari itu poin institusionalisasi paradiplomasi ini dapat berhenti kapanpun bergantung pada keadaan politik dan ekonomi nasional. Penulis tidak menemukan catatan kegiatan yang dilakukan baik Surabaya maupun Kitakyushu yang sesuai dengan poin institusionalisasi ini. Artinya, kerjasama kedua kota tidak sampai pada tingkat partisipasi ini.

\section{KESIMPULAN}

Aktivitas paradiplomasi telah banyak dilakukan untuk meningkatkan kerjasama, salah satunya melalui sister city untuk mempererat hubungan bilateral, seperti yang dilakukan oleh Pemerintah Kota Surabaya dan Pemerintah Kota Kitakyushu. Kerjasama yang dilakukan kedua kota berfokus pada bidang lingkungan yang bertajuk "Green Sister City SurabayaKitakyushu". Berdasarkan pengalaman yang dimiliki Kota Kitakyushu dalam melakukan pembangunan ramah lingkungan menggunakan green technology, Kota Surabaya ingin 
mengikuti jejak Kota Kitakyushu dengan mempelajari teknik pengelolaan sampah dari Kitakyushu. Untuk mewujudkan tujuan tersebut, Surabaya dan Kitakyushu telah menyusun program-program, diantaranya: Konsep Kota Rendah Karbon dan Program Daur Ulang; Water Management; Penggalian Potensi Kota; Pengolahan Air Minum; Pengelolaan Sumber Energi; Penanggulangan Demam Berdarah; Pelestarian Hutan dan Pengembangan Ekowisata. Berkat kerjasama ini, Surabaya berkesempatan untuk menjadi tuan rumah dalam $5^{\text {th }}$ Regional 3R Forum in Asia \& The Pacific, dan disebut sebagai salah satu kota dengan pengolahan terbaik di Indonesia.

Dalam kerjasama sister city ini, penting untuk mengetahui bagaimana pemerintah daerah dapat berkontribusi dalam hubungan internasional dengan mengidentifikasi institusionalisasi dari kerjasama. Institusionalisasi apa saja yang telah dilakukan mulai dari awal penandatangan MoU hingga kontrak kerjasama berakhir. Untuk mengidentifikasi institusionalisasi dari sebuah aktivitas paradiplomasi, terdapat enam institusionalisasi dari kerangka analisis Kuznetsov. Dari ke-enam institusionalisasi, ada empat institusionalisasi yang dilakukan dalam kerjasama ini, diantaranya: pembentukan kementrian atau departemen khusus, kunjungan resmi otoritas regional ke wilayah dan negara asing, partisipasi dalam berbagai acara internasional yang diselenggarakan aktor asing, serta pembentukan dan partisipasi dalam jaringan global \& lintas batas regional multilateral dan kelompok kerja pada bidang tertentu. partisipasi otorisasi daerah dalam acara internasional yang diselenggarakan oleh entitas asing dalam delegasi resmi pemerintah pusat. Sedangkan dua poin institusionalisasi sisanya, kerjasama Surabaya dan Kitakyushu tidak sampai pada tingkat partisipasi tersebut. 


\section{DAFTAR PUSTAKA}

City of Kitakyushu. (2016). Creating Green Cities In Asia Through Intercty Cooperation. Available at:

https://www.env.go.jp/earth/cop/cop22/common/pdf/event/08/01_presentati on4.pdf.

Criekemans, D. (2008). Are the boundaries between paradiplomacy and diplomacy watering down? Preliminary findings and hypotheses from a comparative study of some regions with legislative power and small states., 2nd Global International Studies Conference: What keeps us apart, what keeps us together? International order, justice and value'.

Diskominfo Surabaya. (2020). 'Surabaya Kota Perdagangan dan Kota Industri'. Available at: http://dinkominfo.surabaya.go.id/download.php?id=26.

Duchacek, I. D. (1984). 'The international dimension of subnational self-government', Publius, 14(4). doi: 10.2307/3330188.

Fauzia, F. M. (2019). 'Strategi Pemerintah Surabaya Untuk Mewujudkan Surabaya Green City 2018 Melalui Kerja Sama Green Sister City Dengan Pemerintah Kitakyushu', Skripsi UIN Surabaya.

Government Of Japan. (no date). Concept Of Future City' Initiative, Future City Eco Model City. Available at: https:// future-city.go.jp/en/about/.

Humas Surabaya. (2018). Wali Kota Risma Paparkan Surabaya Dalam Ajang The Guangzhou International Award 2018. Available at: https://humas.surabaya.go.id/2018/12/07/wali-kota-risma-paparkan-surabayadalam-ajang-the-guangzhou-international-award-2018/ (Accessed: 14 April 2021).

Jönsson, C. and Hall, M. (2005). Essence of Diplomacy, Essence of Diplomacy. doi: $10.1057 / 9780230511040$.

KBRI Tokyo. (2017). Surabaya dan Kitakyushu Setuju Tingkatkan Kerja Sama di Berbagai Bidang, Kedutaan Besar Republik Indonesia di Tokyo, Jepang.

Kemendagri Indonesia. (2019). Data Pokok Kemendagri 2019.

Kerjasama Surabaya. (2018a). Kunjungan Delegasi Kitakyushu Terkait Kerjasama Green Sister City, Bagian Administrasi Kerjasama Kota Surabaya. Available at: https:/ / kerjasama.surabaya.go.id/2018/05/kunjungan-delegasi-kitakyushu-terkaitkerjasama-green-sister-city/ (Accessed: 3 April 2021).

Kerjasama Surabaya. (2018b). Kunjungan Delegasi Kota KItakyushu di Kota Surabaya Pada Tanggal 9-13 Januari 2017, Bagian Administrasi Kerjasama Kota Surabaya. Available at: https://kerjasama.surabaya.go.id/kunjungan-delegasi-kota-kitakyushu-di-kotasurabaya-pada-tanggal-9-13-januari-2017/ (Accessed: 3 April 2021). 
Kerjasama Surabaya. (no date). Kerjasama Surabaya-Kitakyushu, Bagian Administrasi Kerjasama Kota Surabaya. Available at: www.kerjasama.surabaya.go.id.

Kitakyushu Initiative for a Clean Environment. (no date). About Us. Available at: https://kitakyushu.iges.or.jp/about/index.html.

Kuznetsov, A. (2014). Theory and Practice of Paradiplomacy, Theory and Practice of Paradiplomacy. doi: 10.4324/9781315817088.

Lecours, A. (2002). 'Paradiplomacy: Reflections on the Foreign Policy and International Relations of Regions', International Negotiation, 7.

Octavia, M. B. (2017). 'Kerjasama Green Sister City Surabaya Dan Kitakyushu (Studi Kasus Pengelolaan Sampah) Melalui Super Depo Suterejo', eJournal Ilmu Hubungan Internasional, 5(2), pp. 685-700.

OECD. (2016). Urban Green Growth in Dynamic Asia, Organisation for Economic Co-operation and Development. Available at: https://www.oecd.org/environment/urban-greengrowth-in-dynamic-asia-9789264266360-en.htm (Accessed: 4 April 2021).

Pandia, A. S. B. (2012). Kerja Sama Surabaya-Kitakyushu Lebih Komprehensif, Kompas.com. Available at: https:/ / regional.kompas.com/read/2012/11/12/19522614/Kerja.Sama.Surabaya -Kitakyushu.Lebih.Komprehensif?page=all (Accessed: 20 April 2021).

Republik Indonesia. (2020). Peraturan Menteri Dalam Negeri Republik Indonesia Nomor 25 Tabun 2020 Tentang Tata Cara Kerja Sama Daerah Dengan Pemerintah Daerah Di Luar Negeri Dan Kerja Sama Daerah Dengan Lembaga Di Luar Negeri. Berita Negara Republik Indonesia Nomor 513 Tahun 2020.

Ridwan, M. (2015a). Atasi Sampah, Surabaya 'Intip' Sejarah Kitakyushu, Lensa Indonesia. Available at: https://www.lensaindonesia.com/2015/10/14/atasi-sampahsurabaya-intip-sejarah-kitakyushu.html (Accessed: 2 April 2021).

Ridwan, M. (2015b). Risma Membangun Surabaya dari Sejarab Kelam Kitakyushu, Lensa Indonesia. Available at: https://www.lensaindonesia.com/2015/10/19/risma-membangunsurabaya-dari-sejarah-kelam-kitakyushu.html (Accessed: 2 April 2021).

Riski, P. (2014). Surabaya, Kota Percontohan Pengolahan Sampab Terbaik Indonesia, Mongabay. Available at: https://www.mongabay.co.id/2014/02/27/surabaya-kotapercontohan-pengolahan-sampah-terbaik-indonesia/.

Tempo.co (2003). Janji Tak Dipenubi, Warga Menutup Tempat Pembuangan Akhir Sampah. Available at: https:// nasional.tempo.co/read/11098/janji-tak-dipenuhi-wargamenutup-tempat-pembuangan-akhir-sampah (Accessed: 1 April 2021).

UNCRD. (2013). Mayor's Forum: Urban Green Growth in Dynamic Asia, United Nations Centre for Regional Development. Available at: 
https:/ /www.uncrd.or.jp/index.php?page $=$ view\&type $=13 \& n r=888 \& m e n u=222$ (Accessed: 4 April 2021).

Walikota Surabaya. (2016). Peraturan Walikota Surabaya Nomor 44 Tabun 2016 Tentang

Kedudukan, Susunan Organisasi, Uraian Tugas dan Fungsi Serta Tata Kerja Sekretariat

Daerah Kota Surabaya. Berita Daerah Kota Surabaya Tahun 2016 Nomor 48.

Wolff, S. (2007). 'Paradiplomacy: Scope, Opportunities and Challenges', The Bologna Center Journal of International Affairs, 10 (1). 